\title{
O OFÍ́CIO TEATRAL NO CONTEXTO DE TRANSFORMAÇÕES URBANAS: A EXPERIÊNCIA DO TEATRO POPULAR UNIÃO E OLHO VIVO
}

Ana Paula Parodi Eberhardt $ه$ 


\section{RESUMO}

O presente artigo é fruto da pesquisa etnográfica realizada acerca das práticas de trabalho do grupo Teatro Popular União e Olho Vivo (TUOV), atuante na cidade de São Paulo, no estado de São Paulo. Descendente do movimento de teatro engajado dos anos sessenta, este grupo se insere na discussão crítica a respeito da mercantilização da arte, e se posiciona de forma antagônica às relações capitalistas de trabalho. Pretende-se, aqui, abarcar uma reflexão sobre as memórias de dois senhores - Idibal Pivetta e Neriney Moreira -, fundadores deste grupo e ainda atuantes nele - referentes aos impactos que o crescimento da cidade de São Paulo trouxe aos seus trabalhos no âmbito artístico e às estratégias por eles utilizadas para transformar as relações de trabalho no interior desta trupe.

Palavras-chave: ofício teatral; memória; antropologia urbana.

\section{L'ARTISANAT THÉÂTRAL DANS LE CONTEXTE DES TRANFORMATIONS URBAINES: L'EXPÉRIENCE DE TEATRO POPULAR UNIÃO E OLHO VIVO}

\begin{abstract}
RÉSUMÉ
Cet article est le résultat de la recherche ethnographique sur les pratiques de travail du groupe Teatro Popular União e Olho Vivo (TUOV), qui opère dans la ville de São Paulo, São Paulo. Descendant du mouvement théâtral engagé des années soixante, ce groupe s'insère dans la discussion critique sur la marchandisation de l'art et se positionne de manière antagoniste aux relations de travail capitalistes. Il est destiné ici à inclure une réflexion sur la mémoire de deux seigneurs - Idibal Pivetta et Neriney Moreira, fondateurs de ce groupe et toujours actifs - sur les impacts de la croissance de la ville de São Paulo sur leurs travaux dans le domaine artistique et les stratégies de ils transformaient les relations de travail au sein de cette troupe.
\end{abstract}

Mots-clés: artisanat théâtral; mémoire; anthropologie urbaine

\section{EL OFICIO TEATRAL EN EL CONTEXTO \\ DE TRANSFORMACIONES URBANAS: LA EXPERIENCIA DEL TEATRO POPULAR UNIÃO E OLHO VIVO}

\section{RESUMEN}

El presente artículo es fruto de la investigación etnográfica sobre las prácticas de trabajo del grupo Teatro Popular União e Olho Vivo (TUOV), actuante en la ciudad de São Paulo, São Paulo. Descendiente del movimiento de teatro comprometido de los años sesenta, este grupo se inserta en la discusión crítica acerca de la mercantilización del arte, y se posiciona de forma antagónica a las relaciones capitalistas de trabajo. La intención de esta propuesta es generar una reflexión sobre las memorias de dos de los fundadores de este grupo (Idibal Pivetta y Neriney Moreira, aún actuantes) sobre los impactos que el crecimiento de la ciudad de São Paulo trajo a sus trabajos en el ámbito artístico, al igual, que las estrategias por ellos utilizadas para transformar las relaciones de trabajo en el interior de esta compañía.

Palabras clave: oficio teatral; memoria: antropología urbana. 


\section{INTRODUÇÃO}

A pesquisa etnográfica mais ampla da qual este artigo se originou versou sobre as memórias e as práticas teatrais do grupo Teatro Popular União e Olho Vivo (TUOV) ${ }^{1}$, percebendo a duração dessas práticas (Eckert \& Rocha 2013) no tempo presente através da remontagem de instantes vividos no interior das dinâmicas urbanas do campo artístico e social da cidade de São Paulo. Esta pesquisa debruçou-se sobre as narrativas de alguns integrantes do grupo teatral, para dar conta da apreensão de instantes que conformam as rupturas e as continuidades que compõem esta duração. Seguindo a linhagem da antropologia urbana, a partir das obras de Velho (1994) e de Magnani (2002), podemos perceber, nessas narrativas, as dinâmicas sociais de criação e de consolidação de um "campo de possibilidades" (Velho 1994), que tornou possível a manutenção deste "projeto coletivo" de teatro (Velho 1994). Como ancoragem importante para essa duração, destaca-se o "potencial de metamorfose" (Velho 1994) de integrantes desta trupe, tanto na manutenção de suas práticas, como nas alterações necessárias a este projeto, no contexto das transformações urbanas ocorridas durante a trajetória de mais de cinquenta anos do grupo.

\section{PERCURSOS DA PESQUISA}

Para esta pesquisa, o trabalho etnográfico foi desenvolvido ao longo de um ano e meio, sendo utilizadas as técnicas de observação participante, escritas de diários de campo, entrevistas e registros audiovisuais junto aos eventos públicos e a atividades de organização interna do grupo.
Entre esses eventos, o de maior relevância foi o acompanhamento da oficina de metodologia de trabalho do TUOV, ocorrida de janeiro a agosto de 2017, dividida em módulos que espelham as comissões de trabalho desta trupe: dramaturgia, musicalidade, cenário, figurino e vídeo. A oficina foi promovida por ocasião das comemorações de 50 anos do TUOV, e, neste projeto comemorativo, ainda foram desenvolvidas a reforma da sede de trabalho, a organização e a abertura de uma exposição da trajetória do grupo, bem como apresentações teatrais de espetáculos do TUOV, interpretados por outros grupos de teatro que partilham a linhagem teatral deste.

Tendo como foco a narrativa, como suporte da memória e reelaboração de experiências, a pesquisa se serviu de entrevistas semiestruturadas, realizadas com três principais interlocutores, todos eles ainda atuantes: César Vieira (nome artístico de Idibal Pivetta), 87 anos, advogado, fundador e dramaturgo do grupo; Neriney Moreira, 74 anos, advogado, fundador e ator; e Cesinha Pivetta, 34 anos, músico, filho de Idibal e ator do TUOV desde criança. Em se tratando de uma pesquisa que segue os fios destas memórias individuais, as quais se tornam coletivas na articulação entre acontecimentos pessoais e sociais, a utilização de alguns longos relatos foi necessária, seguindo pressupostos teóricos de uma etnografia da duração (Eckert \& Rocha 2013).

Dentro da revisão bibliográfica a respeito do grupo teatral e da temática abordada, estão os trabalhos publicados por membros do próprio TUOV, escritos por integrantes dessa trajetória e que foram compilados por César Vieira.

1 Para maiores informações, consultar Eberhardt (2018). 
Essas publicações referem-se ao volume intitulado "Em busca de um teatro popular" (Vieira 2015) e a textos de espetáculos de repertório de Vieira, com acréscimos de críticas de outros dramaturgos e pensadores do teatro paulista.

Além desse material disponibilizado pelo grupo, foi feito um levantamento acerca da bibliografia que discute o tema da arte e suas regras de legitimação, tais como "As regras da arte" e "O poder simbólico", de Pierre Bourdieu (1996, 1989), além de outros escritos que versam sobre a construção do campo teatral brasileiro e discutem a respeito da cultura popular (Ortiz 2006; Hollanda 1980; Jacob 2008; Collaço 2009; Carone 1984).

Entre os trabalhos acadêmicos sobre o TUOV, destaca-se o estudo de Cruz (2012), que, pelo viés historiográfico, analisa e compara o Olho Vivo com a Cia do Latão, ambos identificados como formas contra-hegemônicas de produção teatral. Para a interpretação das entrevistas, foram utilizadas as obras de Paul Ricoeur $(1994,1997)$ e de Eckert \& Rocha $(2005,2013)$ como embasamento teórico, no intuito de perceber as narrativas das memórias dos integrantes como conformação de uma identidade, através da análise do relato de si e da remontagem dos instantes vividos por meio das narrativas biográficas, bem como da construção de trajetórias sociais.

\section{SOBRE O TUOV}

O grupo Teatro Popular União e Olho Vivo originou-se em 1966 na cidade de São Paulo e, desde 1985, tem sua sede no Bairro Bom Retiro. Sendo criado em meio à ditadura civil-militar, manteve suas atividades artísticas atreladas à linhagem de teatro político, com prática engajada na busca por uma linguagem popular. Ao longo de sua trajetória, desenvolveu metodologias de trabalho particulares, que o diferenciam dos demais grupos formados no mesmo cenário cultural.

Todos os trabalhos realizados por essa trupe têm cunho político-social, este é um aspecto peculiar do grupo, que se expressa no conteúdo de suas tramas narrativas nos espetáculos, na divisão de papéis e em suas apresentações, voltadas à população de baixa renda da cidade. Tal escolha faz com que a estética do grupo esteja atrelada a uma ética específica, que pode ser definida como militante e que privilegia a atuação em um circuito teatral não convencional, em oposição às grandes casas de espetáculo.

A prática desse teatro não visa à profissionalização, portanto, todos os integrantes têm seus trabalhos remunerados fora da atividade teatral, dedicando-se às práticas artísticas apenas aos finais de semana. Esta característica de se tratar de um grupo de trabalhadores com orgulho de se declararem como artistas amadores foi bastante frisada pelos interlocutores da pesquisa.

Em decorrência de tal posicionamento, o grupo sobrevive com trabalho voluntário de seus integrantes, algumas vezes contanto com verbas de editais públicos, buscando como primordial a horizontalidade das relações entre seus membros e a divisão de tarefas de forma igualitária: premissas herdadas do movimento comunista das décadas de 1960 e 1970 e que marcam a trajetória do grupo.

No campo teatral, há a prática do que se denomina como "teatro de grupo", uma contraposição ao chamado "teatro de elenco". Nele, verifica-se a permanência de integrantes, 
independentemente do trabalho a ser realizado; já no teatro de elenco, há uma escolha por artistas para compor um trabalho específico, e o grupo não necessariamente se mantém, havendo divisão bem hierarquizada de trabalho, a partir de funções e de remunerações diferenciadas. No TUOV há um discurso de igualdade entre os integrantes sendo o processo de criação compartilhado nas esferas de produção, confecção de figurinos, cenário, dramaturgia entre outros aspectos.

Como já afirmado, os espetáculos são dirigidos ao público morador de bairros periféricos da cidade, e suas temáticas abordam aspectos da história do Brasil, tendo como pano de fundo acontecimentos que retratam um momento - marcante do país (como a Guerra de Canudos, a Revolta da Chibata, a Greve Geral em São Paulo, entre outros), mesclados com a literatura em verso de cordel, com uma trama ligada a elementos da cultura popular (futebol, carnaval, lendas folclóricas, por exemplo). Na encenação, vemos como peculiar o protagonismo de atores negros, o grande número de atores em cena e um não acabamento da obra, que sempre está aberta às mudanças e a novas formas de interpretação.

No momento de formação deste coletivo esse tipo de teatro engajado no Brasil estava em pleno desenvolvimento tanto junto a entidades estudantis, como os Centros Populares de Cultura da União Nacional dos Estudantes (CPC da UNE), quanto ao movimento do Teatro de Arena de São Paulo. Ambos utilizavam essa manifestação artística como forma de comunicação e de conscientização política no combate ao regime militar entre estudantes e classes operárias, partilhando com o TUOV uma rede de conhecimento e de prática teatral.

\section{TRAJETÓRIA SOCIAL E FORMAÇÃO DE UM CAMPO DE POSSIBILIDADES}

O ideal de vida com perspectiva comunitária, que permeia o trabalho teatral do TUOV, já perpassava a formação de uma intelectualidade de esquerda e, neste contexto, tem suas origens no movimento operário paulista, formado no final do século XIX, com a vinda de imigrantes para as lavouras de café2. Se, por um lado, esse processo empreendedor da indústria cafeeira possibilitou a emergência de uma classe abastada que se fixou na cidade, por outro, estabilizou uma classe de operários, em sua maioria composta por estrangeiros. Nesse contexto, surgem centros de cultura, clubes desportivos e sindicatos, que organizaram um movimento cultural, patrocinado por esses operários, de produção de jornais e de teatro ${ }^{3}$. O movimento de teatro popular coloca-se em contraponto com a forma teatral praticada até então, que reforçava a prática de distanciamento entre artistas e público, entre a ficção do palco e a realidade das fábricas: "Para o movimento operário, o teatro e a expressão artística deveriam ser desvinculados dos interesses comerciais [...], visando superar as diferenças formais entre artista/ obra/público" (Jacob 2008:34-35).

A trajetória de Idibal Pivetta é marcada por esses acontecimentos, mesclando elementos da formação de São Paulo com a sua própria vivência.

2 Entre os anos de 1872 a 1910, a população de São Paulo aumentou em 764\%. Para mais informações a esse respeito, ver Carone (1984).

3 Sobre isso, ver Jacob (2008). 
Ele conta que seus avós vieram de navio da Itália e se conheceram ao desembarcar em São Paulo. Seu pai parece ilustrar este emergente italiano, imerso em uma sociabilidade comunitária:

Ele foi fundador do... do PC. Só que não é Partido Comunista, é Partido Constitucionalista. Que foi... começou ali na década de trinta, que foi fundado e começou a estabelecer discussões pra classe operária. Também não seria um partido de esquerda, mas seria um partido politizado burguesmente.. Ele foi eleito e depois foi cassado. [...] Daí, lá em Jundiaí a gente comeu o pão que o diabo amassou... a casa era de piso de... de barro... no bairro do parque São Jorge, que é onde tem o estádio do Corinthians até hoje, né? E tinha esse time Guarani que era verde, chamado Guarani e também era do mesmo bairro, eles tinham toda aquela rivalidade. Hoje não dá pra mensurar esse tipo de coisa, mas... era a comunidade funcionando, através do seus... se não tivesse verba, e não tinha, [...] se virava, fazia jogos, cobrava. [...] Saía uma discussão sobre uma comunidade em andamento. Seria um clube de futebol que joga futebol, mas daí ele chega, vindo da origem dos italianos que vieram pra cá, vieram milhares, né? E que aqui... começaram a trazer todas as... as...atividades deles, comunitárias, dentro do seu setor. Isso é muito importante e são sede do teatro anarquista de São Paulo, o que as origens mesmo nossas seriam isso. (Idibal Pivetta, comunicação pessoal, 30 nov. 2016).

A referência que Idibal traz ao teatro anarquista de São Paulo provém da organização sindical realizada por imigrantes, em sua maioria italianos, que se fixaram na cidade entre o final do século XIX e o início do século XX. Além da produção deste teatro amador, eram veiculados filmes e distribuídos folhetins e jornais feitos por esse operariado, que noticiavam e comentavam eventos das fábricas e dos bairros: uma comunidade em formação, que não tinha acesso aos bens artísticos da elite paulista. Nesse ínterim, o governo da República brasileira institui dois decretos: em 1900, cujo objetivo era "inspecionar as associações públicas de divertimento e recreio, os teatros e espetáculos públicos de qualquer espécie”, e em 1920, instaurando a censura prévia aos espetáculos teatrais e às películas cinematográficas (Jacob 2008:37). Por vezes, essas atividades foram dispersadas por forças policiais, que já vinham se colocando contra as atividades operárias desses setores. O circuito de teatro amador criado por este movimento terá uma importante contribuição para a modernização e o aparecimento de uma vanguarda teatral nos anos 1950 e 1960.

Neriney Moreira, também fundador do TUOV, difere 13 anos da idade de Idibal, mas nos relata experiências similares de uma infância simples, no interior do município de Ubá, em Minas Gerais, muito próxima deste ideal de vida comunitária, não pela política, mas pela vivência do campo e também pelo amor ao futebol:

Eu nasci em 1944 e até os 15 anos de idade eu vivi lá no mato. O pai era roceiro mesmo e cultivava o fumo, [...] ele comercializava o dele que ele plantava e comprava dos vizinhos. Ia com caminhão lotado: quatro, cinco mil quilos e voltava com o caminhão lotado. Vendia. O cara não tinha 
dinheiro pra pagar e "me dá arroz, me dá vinho". [...] Eles pagavam em mercadoria. $\mathrm{E}$ aliado a isso aí toda a minha, a minha, como se diz... o meu crescimento infantil: descalço, pé descalço no chão. Então eu fui criado desse jeito. Pro mato, solto pro mato. No meio dos cachorro, dos cabrito, dos cavalos, sabe...

Meu pai era analfabeto, tanto meu pai quanto a minha mãe, mas tinha essa sabedoria que vem de dentro pra fora do coração... Isso só quem tem e pratica que sabe, isso a gente não aprende em escola não, nem em faculdade, faculdade não ensina isso... [...] Futebol, eu sabia, e jogava. Eu provavelmente seguiria a vida como atleta...

Eu comecei a vir pros bairros em São Paulo, pro futebol, tá me entendendo? Eu jogava no time do IPC, Instituto do Presidente do Café, aqui no centro da cidade. Eu arrumei um emprego no banco e no mesmo prédio funcionava o IPC, e quando chegava todo o sábado e domingo eles iam pro bairro, pra jogar no bairro, e eu ia com eles. Jogava no primeiro e no segundo quadro, ficava sempre no futebol. Só que nessa época, 62, 63, não tinha nem o União e Olho Vivo ainda... Eu comecei a ir pra periferia com o futebol. (Neriney Moreira, comunicação pessoal, 17 fev. 2017).

A infância e a adolescência destes senhores são marcadas por um processo de modernização do país e de surgimento das grandes cidades industriais. Suas trajetórias são permeadas por um movimento de crescimento urbano e de início de uma sociabilidade urbana. Com a instauração do Estado Novo, abriu-se um processo de modernização do país que alterou significativamente a forma de vida dos habitantes das cidades.

Conforme Vera Collaço (2009), no governo de Getúlio Vargas foi instituído o Serviço Nacional de Teatro (SNT), o primeiro organismo estatal criado para atender às demandas do teatro, sua regulamentação e a formação de profissionais técnicos para exercê-la. Essa invenção veio para adequar uma nova arte à efervescência de consolidação do Estado Novo, trazendo novos paradigmas que auxiliassem a superar o "atraso" brasileiro:

[...] O Brasil ainda não conseguiu educar o seu povo ao ponto de se tornar o teatro uma verdadeira exigência de sua civilização. [...] Não basta proteger e amparar o teatro para que ele exista, se antes não são solucionados os problemas de ordem econômica, da difusão do ensino e até o da própria saúde pública. Um povo inculto não é um povo civilizado e o Teatro é um produto espontâneo da civilização (Collaço 2009:6).

A ideia era alavancar a qualidade dos espetáculos encenados, que eram rotulados como de mau gosto, distanciando-se do tradicionalismo popular e mais condizentes ao momento progressista que o país estava vivendo.

Joracy aponta para estatísticas ao afirmar que $80 \%$ da população brasileira era de analfabetos, e que "apenas $2 \%$ da população do Rio de Janeiro podem frequentar teatros" (CAMARGO, 1937:22). Esta população vive em precárias condições econômicas, e, 
consequentemente, não tem condições culturais e intelectuais de apreciar um teatro literário, de boa qualidade. Neste ponto as falas se aproximam, um bom teatro se pauta por um bom texto, que significa um ensinamento moral e cultural, eliminando com isso um teatro cujo único propósito é "a mera diversão" (Collaço 2009:7).

Nesse contexto, o teatro e a cultura artística aparecem como meio civilizador de aprimoramento moral, baseado em um espírito progressista, que auxilie na formação de um Estado desenvolvido. A partir dessas políticas, foram criadas escolas de teatro, cujo modelo era o teatro europeu. Era o caminho de progresso de uma cultura nacional e desenvolvimentista de expansão. A mudança de um país agrário, abrindo-se para a industrialização.

Neriney Moreira narra o episódio de quando saiu do interior de Ubá para a cidade propriamente dita, onde conheceu o cinema, em $1952^{4}$ :

Aprendi a gostar de cinema. Não tinha visão de teatro. Mas cinema: toda aquela produção da Atlântida, com Oscarito, sabe? Grande Otelo? - Eu vi tudo aquilo lá: Flash Gordon, Dick Trace. Era viciado neste negócio. Ficava doente se eu não fosse no cinema. Em Ubá tinha dois cinemas. Mas esse chamava Cine Brasil. Vi tudo, todas as produções... da Atlântida, sabe, aqueles musicais: via tudo!

Existia muito esta coisa de novela. A novelada era da minha época, só que eram dez capítulos, sabe? Tinham os seriados que eram os capítulos, né? - O que vai acontecer com o Dick Trace? Vai dar um tiro, vai morrer? Aí cortava e tu ia ver só na outra [sessão].

Era quarta-feira e sábado, que passava...

O Tarzan... Nossa! A Chita! (Neriney Moreira, comunicação pessoal, 17 fev. 2017).

A temporalidade da vida da primeira metade do século XX traz a memória de uma vida simples e calma, pautada pelo tempo da caminhada tranquila, de ver e ser visto, de uma época diferente, que não existe mais:

\begin{abstract}
Aí eu ia quinta. Depois, no domingo, era o romantismo, os filmes românticos... [A sessão de cinema] era sábado, domingo e quinta-feira, eram esses dias. Aí vai crescendo, vai criando as namoradinhas...

Vai passeando nas praças, vai, fica rondando lá, andando por aquela praça. Mexendo com as menininhas, as menininhas com você.

Aí você namora, namora uma, duas, três, não namora nenhuma...

Namora tudo e não namora nada, sabe? Aquelas coisas... sadias da idade... (Neriney Moreira, comunicação pessoal, 17 fev. 2017).
\end{abstract}

Não era a ditadura de sessenta e quatro, mas era a ditadura do Getúlio [Vargas] e foi tão sangrenta quanto a outra. Tremendamente sangrenta. E aí vem todas as reminiscências pra

4 Dentro do processo desenvolvimentista do país, Getúlio Vargas também é responsável pela alavancada da produção nacional cinematográfica, ocorrida em meados dos anos 1930, com a primeira Lei de Incentivo à Produção Nacional. Franco Zampari, empresário italiano, também criador do Teatro Brasileiro de Comédia (TBC), teve um papel fundamental na distribuição de salas de cinema por São Paulo, sendo fundador da companhia cinematográfica Vera Cruz. 
mim, na minha cabeça é a juventude.. Futebol de bairro, é a escola tal... o footing que é o lugar onde as meninas passeavam e os rapazes ficavam olhando, fazendo sinalzinho e tal. Tudo isso foi ficando... Futebol mesmo nos bairros... [...] O circo passando no bairro, que hoje não tinha mais, os circos são americanizados quando existem. Naquele tempo, não, pô! Eu fiz o Evangelho Segundo Zebedeu, me saiu na cabeça de vir para isso, o circo! Vida, paixão e morte. Vida, paixão e morte de Jesus e nós tivemos a vida, paixão e morte de Antônio Conselheiro, aí eu já fiz essa ligação (Idibal Pivetta, comunicação pessoal, 30 nov. 2016).

A memória das camadas de tempo da vida social se entrelaçam, e é pela narrativa da história de vida, como "vida examinada" (Ricoeur 1997) destes atores sociais, que podemos seguir a meada transformada em fio condutor da significação de si, ordenação de lembranças e esquecimentos, que fazem com que os jogos da memória (Eckert \& Rocha 2005) deem uma possibilidade de duração no tempo e no espaço. A paixão pelo futebol, em especial pelo Corinthians, e o trabalho comunitário vão permear a trajetória de Idibal e darão o tom da atuação do TUOV, que teve muitas de suas peças apresentadas em estádios e/ou com a participação das torcidas organizadas, buscando o popular através do contato com essas camadas da população.

Através da remontagem desses instantes da vida cotidiana no interior da narrativa biográfica, articula-se o tempo vivido e o tempo pensado (Bachelard 1988), em uma intriga que temporaliza a experiência de sujeitos (Ricoeur 1994). Assim, podem-se acessar elementos constituintes de uma memória que é performatizada e que vai para além do indivíduo e de suas experiências pessoais, dando pistas de uma memória coletiva, de experiências análogas e homólogas de rearranjos de si e do mundo social, frente às transformações urbanas contemporâneas.

A chegada à capital traz novas oportunidades e outra configuração para a vida cotidiana. Podemos perceber esta mudança em algumas histórias de Neriney, sobre sua infância e a mudança de sua família de Ubá, em Minas Gerais, para a capital de São Paulo, configurando uma ruptura da sua trajetória:

Eu vim pra cá em 61. [...] O proprietário queria vender, porque descobriram que tinha um projeto pra passar uma avenida lá [Avenida Faria Lima]. Aí o pai disse "vai lá". Vendeu a fazenda e comprou o apartamento. O meu pai não queria de jeito nenhum, meu pai queria voltar... A gente morava em uma fazenda enorme e morar aqui em um apartamento de $\mathrm{x}$ metros quadrados? Pra ele era piada... Cê" trocar uma fazenda, sabe? Aquelas casas velhas, sabe? Janelona de uma porta só. Era tramela, não era fechadura, era tramelada, a gente morava nesse... Tinha cinco quartos, três cozinhas, o terreno tinha 700 metros quadrados, tinha mais de 500 metros quadrados de terreno construído, tinha nossa casa e tinha a casa do nosso empregado que morava junto e ainda sobrava mato pra lá, e ainda tinha a empresa de negócio deles ali... Pra morar aqui em São Paulo em uma avenida, dentro de um apartamento! Tava doidinho pra 
ir embora e voltar. "Ah, vamos voltar!",

"E você vai fazer o que em Ubá? [Aqui] a gente vai estudar" (Neriney Moreira, comunicação pessoal, 17 fev. 2017).

Nessa mudança de estilo de vida, a família de Neriney mudou-se toda para São Paulo (seus sete irmãos e seus pais). Os pais dele não realizaram a formação escolar e viam a necessidade de os filhos virem para a capital paulista para estudar em "escolas boas". Segundo ele, todos fizeram "alguma coisa da vida", referindo-se às graduações dele e de seus irmãos na universidade, os quais adquiriram uma profissão. Neriney conta que, de "tão contrariado" pela mudança de vida, seu pai "não ficou: foi pro outro lado", segundo ele, por não se adaptar à cidade. A narrativa da trajetória de Neri com a morte de seu pai está em consonância com a ruptura com o estilo de vida simples, do campo, para a adesão a um novo projeto de vida: os estudos e a formação de uma carreira. Nesse processo de metamorfose (Velho 1994), Neri ainda não sabia muito bem como se inserir no novo mundo:

Quando eu vim pra São Paulo eu vim no segundo, segunda série ginasial. Eu tive que ficar mais dois anos em São Paulo pra tirar o ginásio, pra saber o que eu queria ser: advogado, médico, dentista, professor... Qualquer coisa eu escolhia...

Aí na época, eu não sei o que eu queria ser... Quando eu comecei a estudar pra escolher uma profissão...

Aí, "vamos fazer o seguinte? Vou ser advogado". Administrador não sabia o que era... Não sabia o que era nada, sabe? Tinha falta de saber o que era as coisas, sabe? Técnico... Tinha essa problemática: o que você vai querer ser? Estudar, estudei. Não tinha este problema.

[...] Quando eu fiz a opção por fazer a faculdade era porque não pagava nada... Aí eu escolhi a São Francisco. Ah, e não pagava nada!

Aí eu comecei a estudar. A concorrência era terrível!

Estudar, eu estudei pra caramba. $\mathrm{Na}$ verdade, eu estudei pra passar.

Eu já trabalhava fora e então eu não tinha muito tempo pra estudar, e então como eu queria entrar sem pagar nada eu... Acho que naquela época era dez por um. Eram dez candidatos por uma vaga... O bicho pegava feio! Tanto que quando eu fiz eu pensei, vou fazer por fazer (Neriney Moreira, comunicação pessoal, 17 fev. 2017).

A chegada à cidade grande foi o período em que esses jovens começaram a ter contato com a produção cultural artística, fruto do desenvolvimentismo nacional. Ambas as lembranças remontam à chegada à capital paulista, como demonstra o relato de Idibal:

Eu tinha uma tia que... até faleceu há pouco tempo, com cem anos. E eu era o sobrinho querido dela. Ela morava com a minha mãe, com minhas irmãs e tal... E ela era louca por teatro e me levava pra assistir todas as peças: Paulo Autran, Tônia Carreiro. Esse pessoal, eu fui quase que engatinhando levado por essa minha tia que chamava Antonieta. [Ela] é que é responsável pela guarda deste acervo [de material gráfico do TUOV]. Quando a gente fala acervo não é o acervo do Olho Vivo, mas o acervo do teatro na 
época, quando se recorta um jornal, uma noticiazinha... Vinha notícia grande e assim..., né? (Idibal Pivetta, comunicação pessoal, 30 nov. 2016)

Neriney, por sua vez, articula sua aproximação com o teatro à alegria de passar no vestibular:

Eu mal sabia somar e multiplicar. Mas história e português eu sabia, tinha facilidade. Aí foi quando eu entrei na faculdade, mais ou menos nessa época que começou a ter o teatro.

Tava muito em voga na época o Arena, o Boal e o pessoal da época... o Zé Celso Martinez, tava com o Oficina, fazendo um sucesso danado...

Aí quando eu entrei na faculdade e começou a sair os resultados, na primeira lista que saiu, já saiu o meu nome.

Eu saí assim, “ah!”, depois da segunda nota, do segundo nome, eu já não vi de mais ninguém! Não vi de mais ninguém! Tava eu lá (risos).

Eu devo ter este recorte, que saiu no Estadão nessa época, até hoje.

$\mathrm{Eu}$ tinha feito na PUC, ali, e nas primeiras notas não tinha saído... Aí na primeira chamada da USP saiu o meu nome (Neriney Moreira, comunicação pessoal, 17 fev. 2017).

A perspectiva de uma vida nova na grande cidade trouxe uma série de rupturas para Neri, que se refere a elas como um conhecimento adquirido de coisas mais sérias, que pareciam não estar ao seu alcance antes:

Quando a gente chegou aqui era 60, eu era uma criançola. Eu não sabia nada. A única coisa que eu sabia era cinema. De cinema, o que tava por cima dos filmes do Mazzaropi, eu não sabia. Não entendia um filme do Mazzaropi! Fazer análise da obra do ator, do Mazzaropi? Eu não tinha esta consciência. Tu tá entendendo? Esta consciência eu adquiri aqui [no TUOV]. Eu sabia ver lá, como se diz? Como diversão. Mas não sabia que por trás daquela diversão tinha coisas mais sérias. Eu não tinha essa consciência, eu aprendi isso aqui (Neriney Moreira, comunicação pessoal, 17 fev. 2017).

O entendimento subjetivo que Neriney foi percebendo como propiciado pela nova cidade trouxe paulatinamente questionamentos sobre coisas mais sérias, em razão de a situação do país também ter se tornado mais densa. A faculdade teve esse papel de mostrar outras possibilidades de perguntas, junto a um movimento de discussão política, que já estava em curso e que esbarrava em um contexto de ditadura:

Você entra em uma faculdade onde os caras só falavam isso [sobre política]. Cê tá entendendo? Entra na faculdade e toda a diretoria tá presa! Presa por quê? É bandido? Em 68, o movimento estudantil tava pegando fogo aqui, eles falaram que ia estourar uma outra queda da bastilha, lá na França... Imagina como tava isso aqui... 20 vezes pior. [...] Aí o União e Olho Vivo nasceu nesta década, logo que eu entrei na faculdade. A diretoria toda presa e o XI queria se manifestar, e achou que a única forma que podia se manifestar era fazer teatro. E pra fazer teatro tinha que desenterrar o Teatro do XI, que tava enterrado. Eles começaram a montar "A peste", de 
Albert Camus, e foi todo mundo preso. Aí foi quando chamaram o César, que já era um pouco mais velho que eu e já era advogado... Aí o César trouxe o texto do Zebedeu. (Neriney Moreira, comunicação pessoal, 17 fev. 2017).

Os ideais de transformação social se alastravam pelo mundo e Neri, agora por meio do teatro e da universidade, via mais longe do que o cinema mostrava. O movimento de contracultura ganhava força e seus rumores já podiam ser sentidos como promessa de uma nova "queda da bastilha". Nesse contexto, ele conhece Idibal:

Tinha um cartaz "precisa-se de 40 trabalhadores". Eu me lembro muito bem. Escrito que era pra fazer o teatro. E foi na época em que eu entrei. Não sabia o que era ator. Via nas novelas, o Paulo Autran, que também era advogado mas ganhava a vida como ator (formado também pela São Francisco), a Fernanda Montenegro, tudo novinho. Aí eu comecei a conhecer este pessoal nessa época. Aí o Zebedeu foi minha primeira experiência. Aí com o Zebedeu a gente começou a fazer as primeiras transformações. Vamos fazer teatro. Mas que teatro? A única coisa que o pessoal via é que tinha muita peça estrangeira. E não tinha brasileira nenhuma; aí a gente começou a pegar e, "vamos fazer peça brasileira". Aí o César como autor (Neriney Moreira, comunicação pessoal, 17 fev. 2017).

Acompanhando as transformações urbanas que ocorriam à sua volta, bem como os reflexos de uma nova organização social, pautada pelo ritmo do trabalho na consolidação do sistema capitalista industrial, esses jovens foram testemunhas de alterações drásticas no ritmo da vida cotidiana que trouxeram consequências importantes para suas vidas e para o país. Além do trabalho junto ao teatro, Idibal atuou como advogado de presos políticos durante a ditadura militar, momento em que adotou o pseudônimo de César Vieira, para burlar a censura a seus textos.

O crescimento de São Paulo como uma grande metrópole estabeleceu novas formas de sociabilidade e de subjetivações de si. Podemos perceber este movimento à luz dos escritos de Simmel (2005), a respeito da relação entre a metrópole e a vida mental de seus habitantes.

Simmel (2005) discute a ideia de que os diversos estímulos de uma cidade grande nos trazem uma atitude de indiferença e reserva, tornando-nos menos sensíveis aos acontecimentos da vida cotidiana, em razão de objetivarmos mais as relações interpessoais subjetivas. Segundo ele, isso se dá pelo processo de individualização crescente que a monetarização propiciou ao indivíduo moderno da metrópole. Seguindo neste raciocínio, temos a dinâmica da cidade como construtora dessas relações, a partir de uma lógica de mercado e de produção, onde as trocas exercidas estão calcadas na objetividade das trocas monetárias, que trazem impessoalidade para as relações e exprimem, com rigor qualitativo, o valor das trocas:

Na medida em que o dinheiro, com sua ausência de cor e indiferença, se alça a denominador comum de todos os valores, ele se torna o mais terrível nivelador, ele corrói irremediavelmente o núcleo das coisas, sua peculiaridade, seu valor específico, sua incomparabilidade. Eis porque as cidades grandes, centros, a circulação de dinheiro e nas quais a venalidade das coisas se impõem em uma 
extensão completamente diferente do que nas situações mais restritas (Simmel 2005:582).

Frente à ameaça de fragmentação, característica das grandes cidades (Velho 1994), estes senhores encontraram no trabalho teatral comunitário, de cunho político e social, uma forma de duração de si, criando, através do teatro, um espaço de resistência às lógicas mercantis e impessoais da metrópole. Por ter caráter efêmero e subjetivo, o teatro passou a ser visto como uma potente ferramenta pedagógica de percepção e de ação no mundo social. Segundo César Vieira (2015:48), "O teatro foi o meio que escolhemos para participar. O meio para dizer presente. O meio para lutar pela transformação da sociedade. A forma de integrarmonos no processo de emancipação do homem”.

Por meio deste compromisso ético, que se reflete na sua estética e na sua organização de trabalho, a formação do ator se dá por um processo pedagógico, desenvolvido pelo grupo, que visa abranger o indivíduo em sua totalidade. Assim, a relação de ensino/aprendizado realizada no interior deste coletivo também se coloca como um meio para essa transformação social mais ampla, sendo incorporada nos processos de organização interna que se contrapõem à lógica hierarquizante da sociedade. Nessa perspectiva, o desenvolvimento formativo e cotidiano dos trabalhos do grupo denota uma aderência a um ethosespecífico de coletividade e de solidariedade, que se reflete nas dimensões de criação e de execução de seus espetáculos, bem como na relação com seus integrantes e seu público.

\section{UM TEATRO DE OPOSIÇÃO}

Na busca por um teatro popular, o TUOV busca refletir e incorporar as críticas à indústria cultural à sua forma de trabalho. Um dos aspectos mais relevantes desta forma de se opor à visão da arte como mercadoria é a opção desta trupe em deixar sua obra teatral, o espetáculo, aberta a modificações, mantendo-a inacabada, mesmo após a sua estreia. Também a não profissionalização de seus atores, distanciando-se da formação especializada tradicional e da divisão do trabalho nos moldes capitalistas. De acordo com Pâmela Peregrino da Cruz (2012), esta forma de trabalho pode ser considerada como contra-hegemônica, pois subverte a lógica dos modos de produção da arte. Operando por essa outra maneira de se colocar no mundo artístico, o TUOV busca formas de financiamento que fogem dos meandros da disputa na indústria cultural. Cesinha Pivetta conta, em entrevista, que o grupo se manteve financeiramente, ao longo dos anos, por uma tática chamada de "Robin Hood":

Que era vender o espetáculo pra um
público que tinha condições de pagar,
pra burguesia, e aplicar [o dinheiro] em
vários espetáculos pra um que nunca
tinha visto teatro, sabe? Um que queria
ver mais uma peça "ah eu quero ver
mais uma peça agora!" e pagava pra
isso, e outro que nunca tinha visto e a
gente chegava e fazia espetáculo pra
vários... Aplicava isso e sobreviveu
assim, sem os atores receberem
nunca porque trabalhavam só fim de
semana no teatro (Cesinha Pivetta,
comunicação pessoal, 31 out. 2016).

Essa crítica ao teatro profissional aparece em muitas falas de César Vieira. Segundo ele, esta forma de produção mantém e reforça uma estrutura desigual de classes, tanto pela sua lógica de trabalho hierarquizante de produção quanto na 
estrutura das apresentações e na relação com o público. O palco elevado, que distancia os atores do público, e a cotação do preço do ingresso, que varia de acordo com a possibilidade de assistir mais ou menos plenamente a um espetáculo, reforçam essa desigualdade econômica e a manutenção dos privilégios de quem pode pagar para ver arte.

César aponta o longo processo de enfrentamento da censura ocorrido durante a ditadura, e afirma que, hoje em dia, a censura está ainda presente, mas agora ela se traveste de censura econômica. As formas de financiamento para um espetáculo, no geral, passam pela escrita de um projeto a um edital, seja público ou privado, cerceando a liberdade artística e criativa. Isso também ocorre pelo fato de a temática do edital ser escolhida pelo promotor do certame para nortear o espetáculo, ou pelo fato de o cumprimento dos prazos ser restrito, reduzindo, assim, o tempo de pesquisa de linguagem a se enquadrar na previsão de prazo dada pelo edital, sem a possibilidade de grandes alterações neste processo.

A ideia de não profissionalização de seu ofício esta imbricada com a proposta de se distanciar deste controle e cerceamento da indústria de mercado, opondo-se à noção de teatro como mercadoria e reafirmando-o enquanto ferramenta de "emancipação do homem". Isso está em consonância com os escritos de Walter Benjamin (1985), em seu texto "O autor como produtor", no qual ele reflete que a arte que visa alcançar uma transformação social, na busca por uma sociedade mais igualitária e justa, tem o dever de repensar e reestruturar seu trabalho de forma revolucionária, discutindo seu papel e sua relação enquanto meio de produção. Benjamin (1985) alerta para o fato de que, neste caso, o autor não deve ser apenas um intelectual apartado dos demais setores da sociedade, mas sim um produtor, estreitando os laços de solidariedade com as demais classes trabalhadoras.

A eficácia desta arte revolucionária deve colocar em cheque a própria estrutura dominante política e econômica, não buscando apenas uma alteração na forma de seu produto final, mas ampliando tal atitude reflexiva para a práxis de transformação em seu meio de produção, buscando uma função organizativa do trabalho. Caso contrário, o trabalho pode ser identificado como contrarrevolucionário, sendo assimilado pela estrutura de dominação hegemônica, transformando-se em mais um artigo de consumo.

Sobre esse movimento de arte engajada neste período no país, temos o importante relato de Heloísa Buarque de Hollanda, que faz uma crítica a esse respeito:

\footnotetext{
Fracassada em suas pretensões revolucionárias e impedida de chegar às classes populares, a produção cultural engajada passa a realizar-se num circuito nitidamente integrado ao sistema - teatro, cinema, disco e a ser consumido por um público já “convertido" de intelectuais e estudantes da classe média (Hollanda 1980:30).
}

A discussão sobre a prática artística popular, e o próprio conceito do que é considerado popular ou não, é um fator decisivo na mudança das práticas do TUOV. Em 1978, a atividade artística foi regulamentada como profissional no país, trazendo consigo uma série de normatizações. 
Em consequência e somando-se a isso, a expansão dos meios de comunicação em massa fez com que muitos atores dos teatros engajados deste período migrassem suas carreiras para a televisão e o cinema, visando, com isso, que seu discurso pudesse abranger maior número de pessoas. É este movimento que acaba sendo duramente criticado como algo que vinha se tornando uma nova mercadoria, absorvida pela indústria e reforçando o distanciamento do artista intelectual, apartado do povo. Seguindo os preceitos do lema da época, que diz que a arte deve ser feita pelo povo, para o povo e onde o povo está, o TUOV seguiu o caminho oposto à massificação, voltandose para as apresentações nos bairros de periferia, para discutir junto com o público seus problemas:

Acentuava-se o entendimento de que deveríamos permanecer por mais tempo no local dos espetáculos, para aprofundar a troca de experiências.

[...] Estabelecemos que o ideal seria a permanência por quinze dias em cada comunidade. [...] Algumas entidades [que nos solicitavam] queriam que fizéssemos um só espetáculo para reunir gente motivada pela encenação e, depois, durante o debate das questões que o espetáculo levantava, propor a discussão de um tema específico: a urgente necessidade de uma escola para o bairro, a canalização de um córrego, etc. [...] O espetáculo, pelo seu tema, se prestava a suscitar questões. De seu conflito central, a luta pela liberdade, passava-se facilmente à ampla discussão da conquista da liberdade verdadeira, a liberdade primeira de poder o homem ter uma vida digna, de poder comer, vestir, estudar (Vieira 2015:110-111).
Essa prática de longa duração do Olho Vivo transformou-se em uma das principais características do grupo que, optando por não fazer parte do circuito comercial de teatro, dedicou e dedica seu trabalho para que o público que ainda não acessa o direito à arte possa ser contemplado.

Esse ponto de relação do grupo com o seu público mostra-se como uma interessante marca deste coletivo. Buscando uma relação mais horizontal com o espectador, o grupo conseguiu se destacar dos demais coletivos teatrais da época de seu contexto de criação e adensar a discussão sobre cultura popular. Deste encontro, muitos foram os espectadores que se aproximaram do grupo e se transformaram em atores dos espetáculos. Assim, o TUOV conseguiu colocar em prática seu ideal de distribuição dos meios de produção teatral ao povo, invertendo a lógica mercantil mais ampla e distribuindo o protagonismo.

\section{CONSIDERAÇÕES FINAIS}

A partir do potencial de metamorfose, no rearranjo do projeto coletivo do TUOV, podemos perceber a continuação de uma linhagem teatral engajada, ancorada em princípios éticos de solidariedade entre seus integrantes. Trilhando este caminho, o grupo se faz construtor de um campo de possibilidades do teatro como um evento de encontro e de compartilhamento, onde a partilha do sensível possibilita a duração das relações através do tempo. Neste movimento, a contra-hegemonia desta trupe destaca-se por suas práticas externas e internas.

Quando os senhores entrevistados nesta pesquisa chegaram à cidade de São Paulo, em meados do século XX, a transformação de 
um campo de possibilidades estava em plena atuação, trazendo para a experiência individual a necessidade de construir um projeto de vida que se ajustasse a uma nova lógica. Buscando uma não ruptura drástica de suas trajetórias, até então construídas, eles encontraram no fazer artístico de caráter engajado e político uma forma de duração de si. Mas, mesmo o campo artístico, que parecia propício para a continuidade de um projeto pessoal, tornou-se hostil, no sentido da irrupção de um contexto ditatorial, que marcou deserções forçadas e voluntárias, e onde uma nova possibilidade se abriu: a indústria cultural, que absorveu muitos de seus contemporâneos. A continuidade de seus pressupostos frente a isso tornou-se uma resistência, que, longe de ser ingênua, foi "maliciosa", pelo potencial de metamorfose que continha e que desenvolveu.

Agindo a partir do ideal de transformação da sociedade, o Olho Vivo busca que seus trabalhos externo (o espetáculo) e interno (sua organização) - sejam parte desse processo de emancipação. Se, como afirma Cruz (2012), a atuação do grupo pode ser encarada como contra-hegemônica, por se colocar à margem do sistema capitalista da indústria cultural, em sua prática cotidiana interna também percebo este mesmo movimento de se contrapor à lógica social mais ampla, em razão de estes indivíduos estabelecerem uma proposição organizativa que difere das relações concorrentes, anônimas e blasés da grande cidade.

Por se manter como um grupo de teatro amador, o TUOV consegue não se submeter à lógica mercantil da arte profissional, e esta prerrogativa acarreta uma experiência peculiar, no que se refere à relação com o trabalho. Se, por um lado, o dia a dia profissional fora do TUOV traz uma relação de obrigação, pela necessidade da geração de renda pessoal, por outro, o ofício dentro dele traz uma possibilidade de conjugar o lazer e a autonomia.

\section{REFERÊNCIAS}

Bachelard, G. 1988. A dialética da duração. São Paulo: Editora Ática.

Benjamin, W. 1985. O autor como produtor, in Walter Benjamin: magia e técnica, arte e política. pp. 120-136. São Paulo: Brasiliense.

Bourdieu, P. 1989. O poder simbólico. Rio de Janeiro: Bertrand Brasil S.A.

Bourdieu, P. 1996. As regras da arte: gênese e estrutura do campo literário. São Paulo: Companhia das Letras.

Carone, E. 1984. Movimento operário no Brasil (1877-1944). 2. ed. São Paulo: Difel.

Collaço, V. R. M. 2009. Três projetos de modernização para o teatro brasileiro e suas relações com as políticas culturais do Estado Novo. Anais do Simpósio Nacional de História 25:1-12.

Cruz, P. P. 2012. A relação/tensão entre arte e capital no Brasil: a atuação de grupos teatrais contra hegemônicos (1990-2010). Dissertação de Mestrado, Departamento de História, Universidade Federal Fluminense, Niterói.

Eberhardt, A. P. P. 2018. "União olho vivo e pé ligeiro": estudo etnográfico das memórias e 
duração das práticas do teatro popular União e Olho Vivo na cidade de São Paulo/SP. Dissertação de mestrado, Departamento de Antropologia Social, Universidade Federal do Rio Grande do Sul, Porto Alegre.

Eckert C., e A. L. C. Rocha. 2005. O tempo e a cidade. Porto Alegre: Editora UFRGS.

Eckert, C., e A. L. C. Rocha. 2013. Etnografia da duração: antropologia das memórias coletivas nas coleções etnográficas. Porto Alegre: Marcavisual.

Hollanda, H. B. 1980. Impressões de viagens: CPC, vanguardas e desbunde, 1960-1970. São Paulo: Brasiliense.

Jacob, M. M. 2008. Na cena paulista, o teatro amador: circuito alternativo e popular de cultura (1927-1945). São Paulo: Ícone.

Magnani, J. G. C. 2002. De perto e de dentro: notas para uma etnografia urbana. Revista Brasileira de
Ciências Sociais 17(49):11-29. DOI: http://dx.doi. org/10.1590/S0102-69092002000200002.

Ortiz, R. 2006. Cultura brasileira e identidade nacional. 5. ed. $9^{a}$ reimpressão. São Paulo: Brasiliense.

Ricoeur, P. 1994. Tempo e narrativa. Campinas: Papirus.

Ricouer, P. 1997. Tempo e narrativa III. Tradução de Roberto Leal Ferreira. Campinas: Papirus.

Simmel, G. 2005. As grandes cidades e a vida do espírito. Mana 11(2):577-591. DOI: http://dx.doi. org/101590/S0104-93132005000200010.

Velho, G. 1994. Projeto e metamorfose: antropologia das sociedades complexas. Rio de Janeiro: Jorge Zahar.

Vieira, C. 2015. Em busca de um teatro popular. São Paulo: SMC. 